\title{
UNIVERSITY OF LUND RADIOCARBON DATES VIII
}

\author{
SÖREN HAKANSSON
}

Radiocarbon Dating Laboratory, Department of Quaternary Geology

University of Lund, Sweden

\section{INTRODUCTION}

Most of the ${ }^{14} \mathrm{C}$ measurements reported here were made between October 1973 and October 1974. Equipment, measurement, and treatment of samples are the same as reported previously $(\mathrm{R}, 1968, \mathrm{v} 10$, p 36-37; 1970, v 12, p 534).

Age calculations are based on a contemporary value equal to 0.950 of the activity of NBS oxalic acid standard and on the conventional half-life for ${ }^{14} \mathrm{C}$ of $5568 \mathrm{yr}$. Results are reported in years before 1950 (years $\mathrm{BP}$ ), and in the $\mathrm{AD} / \mathrm{BC}$ system. Errors quoted $\left( \pm 1_{\sigma}\right)$ include standard deviations of count rates for the unknown sample, contemporary standard, and background. When measured activity is less than $2 \sigma$ above background, minimum age is given. Basis for calculation of age limit is measured net activity plus $3 \sigma$. If net activity is negative, only $+3 \sigma$ is used for age limit.

Corrections for deviations from $\delta^{13} \mathrm{C}=-25.0 \%$ in the $\mathrm{PDB}$ scale are applied for all samples; also for marine shells, because apparent age of recent marine shells is not always just counterbalanced by the effect of isotopic fractionation ( $c f$, Recent marine shells series, R, 1973, v 15, p 506-507). $\delta^{13} \mathrm{C}$ values quoted are relative to the PDB standard.

The remark, "undersized; diluted", in Comments means the sample did not produce enough $\mathrm{CO}_{2}$ to fill the counter to normal pressure and "dead" $\mathrm{CO}_{2}$ from anthracite was introduced to make up the pressure. "\% sample" indicates amount of $\mathrm{CO}_{2}$ derived from the sample present in the diluted counting gas; the rest is "dead" $\mathrm{CO}_{2}$. Organic carbon content reported for bone sample is calculated from yield of $\mathrm{CO}_{2}$ by combustion of pretreated collagen. Organic carbon lost during treatment is not included in calculated percentage.

The description of each sample is based on information provided by the submitter.

\section{ACKNOWLEDGMENTS}

The author thanks Kerstin Lundahl for sample preparations and routine operation of the dating equipment, and $R$ Ryhage and his staff at the mass-spectrometric laboratory of Karolinska Inst, Stockholm, for the ${ }^{13} \mathrm{C}$ analyses.

\section{SAMPLE DESCRIPTIONS}

I. GEOLOGIC SAMPLES

\section{Tuorkanådas series}

\section{A. Sweden}

Peat from palsa, ie, permafrost mound, SE of Tuorkanådas, Torne Lappmark, N Sweden (68 $\left.38^{\circ} \mathrm{N}, 1^{\circ} 00^{\prime} \mathrm{E}\right)$. Coll 1972 by $\mathrm{N} \AA$ Andersson; subm by $M$ Sonesson, Dept Plant Ecol, Univ Lund. Dating 
is part of study on peat development in Torneträsk area (Sonesson, 1968, 1974).

Lu-833. Tuorkanådas, 14 to $15 \mathrm{~cm}$

$9310 \pm 180$ $7360 \mathrm{BC}$

$\delta^{13} \mathrm{C}=-24.2 \%$

Peat from 0 to $1 \mathrm{~cm}$ above mineral substratum. Comment: mild pretreatment with $\mathrm{HCl}$ and $\mathrm{NaOH}$; small sample; diluted; $43 \%$ sample.

Lu-832. Tuorkanådas, 13 to $14 \mathrm{~cm}$, peat

$8960 \pm 140$

$7010 \mathrm{BC}$

$\delta^{13} C=-23.6 \%$

Peat from 1 to $2 \mathrm{~cm}$ above mineral substratum. Comment: normal pretreatment with $\mathrm{HCl}$ and $\mathrm{NaOH}$; diluted; $55 \%$ sample.

\section{$\mathbf{8 8 9 0} \pm 90$ \\ Lu-832A. Tuorkanådas, 13 to $14 \mathrm{~cm}$, humic acid $6940 \mathrm{BC}$ \\ $\delta^{13} \mathrm{C}=-24.8 \%$}

Acid-precipitated part of $\mathrm{NaOH}$-soluble fraction from $\mathrm{Lu}$-832. Comment: diluted; $72 \%$ sample (3 1-day counts.) Agreement between fractions indicates contamination is absent or insignificant.

\section{Södra Bergundasjön series}

Sediment from Lake Södra Bergundasjön at town of Växjö, Central Småland $\left(56^{\circ} 51^{\prime} \mathrm{N}, 13^{\circ} 47^{\prime} \mathrm{E}\right)$. Coll 1972 and subm by L Bengtsson, Dept Limnol, Univ Lund. Dated to determine rate of sediment deposition. Depths refer to sediment surface. Mild pretreatment with HCl and $\mathrm{NaOH}$.

\section{Lu-860. Södra Bergundasjön, 55 to $60 \mathrm{~cm}$}

$660 \pm 55$

AD 1290

$$
\delta^{18} C=-25.1 \%
$$

Detritus gyttja. Comment: undersized; diluted; $87 \%$ sample.

Lu-861. Södra Bergundasjön, 120 to $125 \mathrm{~cm}$

Detritus gyttja.

$$
\begin{array}{r}
\mathbf{6 2 0} \pm \mathbf{5 0} \\
\mathbf{A D} 1330 \\
\delta^{13} C=-25.1 \%
\end{array}
$$

\section{Trummen series}

Sediment from Lake Trummen, Central Småland $\left(56^{\circ} 52^{\prime} \mathrm{N}, 14^{\circ} 50^{\prime}\right.$ E). Coll 1974 and subm by G Digerfeldt, Dept Quat Geol, Univ Lund. Dates were part of study of Late glacial development of lake and surrounding landscape. Other dates in series were reported previously $(\mathrm{R}$, 1968 , v 10, p 40-43; 1969, v 11, p 434; 1970, v 12, p 535-536). Major results of Postglacial studies are pub by submitter (Digerfeldt, 1972). Depths refer to water surface. Water depth ca $1.7 \mathrm{~m}$. Sample Lu-944 consists of clayey gyttja; all other samples are clay gyttja. Pretreated with HCl. All samples except Lu-944 were undersized and therefore diluted. Amount of $\mathrm{CO}_{2}$ from sample is given in Comments below as "\% sample". 
Lu-936. Trummen, 664 to $666 \mathrm{~cm}$

Comment: $65 \%$ sample. (3 1-day counts.)

Lu-937. Trummen, 648 to $652 \mathrm{~cm}$

Comment: $53 \%$ sample. (3 1-day counts.)

Lu-938. Trummen, 636 to $640 \mathrm{~cm}$

Comment: $64 \%$ sample. (4 1-day counts.)

Lu-939. Trummen, 622 to $626 \mathrm{~cm}$

Comment: $63 \%$ sample.

Lu-940. Trummen, 608 to $612 \mathrm{~cm}$

Comment: $64 \%$ sample.

Lu-941. Trummen, 594 to $598 \mathrm{~cm}$

Comment: $70 \%$ sample.

Lu-942. Trummen, 580 to $584 \mathrm{~cm}$

Comment: $91 \%$ sample.

Lu-943. Trummen, 566 to $570 \mathrm{~cm}$

Comment: $89 \%$ sample.

Lu-944. Trummen, 552 to $556 \mathrm{~cm}$

Lu-989. Trummen, Complementary Sample 1

Comment: $55 \%$ sample. (3 1-day counts.)

Lu-990. Trummen, Complementary Sample 2

Comment: $42 \%$ sample. (3 1-day counts.)
$11,670 \pm 130$

9720 BC

$\delta^{13} C=-20.5 \%$

$12,330 \pm 165$

$10,380 \mathrm{BC}$

$\delta^{13} \mathrm{C}=-19.0 \%$

$12,030 \pm 135$

10,080 BC

$\delta^{13} C=-19.7 \%$

$11,820 \pm 160$

9870 BC

$\delta^{13} C=-18.5 \%$

$11,390 \pm 155$

9440 BC

$\delta^{13} C=-18.5 \%$

$10,990 \pm 145$

9040 BC

$\delta^{13} \mathrm{C}=-20.0 \%$

$10,670 \pm 115$

8720 BC

$\delta^{13} \mathrm{C}=-22.3 \%$

$10,300 \pm 110$

8350 BC

$\delta^{13} \mathrm{C}=-21.4 \%$

$10,120 \pm 100$

8170 BC

$\delta^{13} C=-21.5 \%$

$11,180 \pm 145$

$9230 \mathrm{BC}$

$\delta^{13} C=-21.8 \%$

$12,280 \pm 185$

10,330 вC

$\delta^{13} C=-21.5 \%$ 


\section{Lu-962. Barsebäcksmossen, 902.5 to $907.5 \mathrm{~cm}$}

Brackish clayey gyttja from early part of AT 2. Coll 1969 and subm by $G$ Digerfeldt. Main series from this site was pub previously ( $R, 1973$, v 15, p 496-499). Comment: pretreated with $\mathrm{HCl}$.

\section{Järlasjön series}

Sediment from Lake Järlasjön at Nacka, Stockholm $\left(59^{\circ} 18^{\circ} \mathrm{N}\right.$, $\left.18^{\circ} 06^{\prime} \mathrm{E}\right)$. Coll 1972 and subm by $\mathrm{G}$ Digerfeldt. Dated as part of study on laminated sediments. Samples consist of clay gyttja. Pretreated with $\mathrm{HCl}$.

\section{Lu-905. Järlasjön 1}

$$
940 \pm 65
$$

AD 1010

Comment: undersized; diluted; $56 \%$ sample.

$\delta^{1 s} C=-28.0 \%$

\section{Lu-906. Järlasjön 2}

$$
1360 \pm 60
$$

AD 590

Comment: undersized; diluted; $69 \%$ sample.

\section{Hinnasjön series}

Sediment from Lake Hinnasjön, ca $7 \mathrm{~km} \mathrm{E}$ of town of Växjö, Central S Sweden $\left(56^{\circ} 53^{\prime} \mathrm{N}, 14^{\circ} 56^{\prime} \mathrm{E}\right)$. Coll 1973 by Th Persson; subm by G Digerfeldt. Dated with study of Late Postglacial vegetational history of surrounding landscape. Dates also used to determine rate of sediment deposition to calculate absolute pollen frequency per $\mathrm{cm}^{2}$ per year. Pollen analyses by Th Persson. Depths refer to sediment surface. Water depth at sampling point, $2.7 \mathrm{~m}$. All samples consist of fine detritus gyttja, and were pretreated with $\mathrm{HCl}$ and $\mathrm{NaOH}$. Seven samples undersized; diluted. Amount of $\mathrm{CO}_{2}$ from sample is given in Comments below as "\% sample".

\section{Lu-960. Hinnasjön, 311 to $316 \mathrm{~cm}$}

Comment: $80 \%$ sample.

\section{Lu-961. Hinnasjön, 241 to $246 \mathrm{~cm}$}

Decrease of Quercus, Ulmus, and Corylus.

\section{Lu-959. Hinnasjön, 179 to $184 \mathrm{~cm}$}

Distinct increase of Fagus. Comment: $68 \%$ sample.

Lu-921. Hinnasjön, 144 to $149 \mathrm{~cm}$

$$
\begin{aligned}
& 3590 \pm 65 \\
& 1640 \mathrm{BC} \\
& \delta^{19} C=-29.2 \% \\
& 2700 \pm 55 \\
& 750 \text { BC } \\
& \delta^{1 s} C=-29.8 \% \text { 。 } \\
& 2190 \pm 70 \\
& 240 \text { BC } \\
& \delta^{13} C=-30.1 \% \text { 。 } \\
& 1950 \pm 50 \\
& \mathrm{AD} / \mathrm{BC} \mathbf{0} \\
& \delta^{13} C=-29.7 \% \text { 。 }
\end{aligned}
$$


Lu-920. Hinnasjön, 114 to $119 \mathrm{~cm}$

$$
1790 \pm 55
$$

AD 160

$\delta^{13} C=-29.3 \%$ o

Beginning of last maximum of Quercus; just below maximum of Carpinus; Fagus reaches 1\%. Comment: $87 \%$ sample.

Lu-958. Hinnasjön, 90 to $92.5 \mathrm{~cm}$

$$
\begin{gathered}
1400 \pm 65 \\
\text { AD 550 } \\
\delta^{13} C=-29.8 \%
\end{gathered}
$$

Decrease of Alnus and Carpinus. Comment: $60 \%$ sample.

\section{Lu-864. Hinnasjön, 50 to $52.5 \mathrm{~cm}$}

$$
\begin{gathered}
1080 \pm 60 \\
\text { AD 870 } \\
\delta^{13} \mathrm{C}=-30.0 \%
\end{gathered}
$$

Decrease of Betula; Juniperus reaches 1\%. Comment: $69 \%$ sample.

Lu-863. Hinnasjön, 35 to $37.5 \mathrm{~cm}$

Rational Picea limit. Comment: 59\% sample.

Lu-862. Hinnasjön, 12.5 to $15 \mathrm{~cm}$

$$
\begin{array}{r}
\mathbf{9 3 0} \pm \mathbf{6 5} \\
\mathbf{A D} \mathbf{1 0 2 0} \\
\delta^{13} C=-30.0 \%
\end{array}
$$

AD 1350

$600 \pm 65$

$\delta^{13} C=-28.9 \%$

Culmination of Fagus; further increase of Picea and Juniperus. Comment: $61 \%$ sample.

\section{Härryda series}

Wood from 2 exposures at Härryda, SW Sweden. Coll 1973 and subm by A Hilldén, Dept Quaternary Geol, Univ Lund. Dating is part of study on hydrology in area.

\section{Lu-889. Härryda, Sample 1}

$$
\begin{gathered}
3920 \pm 60 \\
1970 \text { BC } \\
\delta^{13} C=-27.0 \%
\end{gathered}
$$

Wood fragments (Alnus sp) id by $\mathrm{T}$ Bartholin from light clay below $1.5 \mathrm{~m}$ coarse river gravel at Hwy 40 bridge over Tvärån, Härryda $\left(57^{\circ}\right.$ $\left.41^{\prime} 33^{\prime \prime} \mathrm{N}, 12^{\circ} 19^{\prime} 43^{\prime \prime} \mathrm{E}\right)$. Comment: pretreated with HCl.

\section{Lu-888. Härryda, Sample 2}

$$
\begin{gathered}
2260 \pm 55 \\
310 \mathrm{BC} \\
\delta^{13} \mathrm{C}=-28.3 \%
\end{gathered}
$$

Wood from stump (Alnus sp) id by $\mathrm{T}$ Bartholin from light clay below $1.0 \mathrm{~m}$ of coarse river gravel in new brook furrow, $350 \mathrm{~m}$ ESE of Härryda church $\left(57^{\circ} 41^{\prime} 27^{\prime \prime} \mathrm{N}, 12^{\circ} 19^{\prime} 00^{\prime \prime} \mathrm{E}\right)$. Comment: pretreated with $\mathrm{HCl}$ and $\mathrm{NaOH}$.

\section{Tomtabacken series}

A kerhultagöl is a mire pool, $1 \mathrm{~km} \mathrm{SW}$ of Tomtabacken, highest hill of South Swedish Upland (57 $\left.29^{\prime} \mathrm{N}, 14^{\circ} 28^{\prime} \mathrm{E}\right)$. Alt of pool: $+303 \mathrm{~m}$; size: ca $300 \times 100 \mathrm{~m}$. Samples are from core taken from mire surface in 
SW part with Livingstone sampler (100mm diam). This is a Late Weichselian standard profile within a project on S Swedish paleoecology. It is part of study on deglaciation of this upland. Coll 1973 and subm by B E Berglund, Dept Quaternary Geol, Univ Lund. Depths refer to surface of mire. Pollen zones according to Nilsson (1961) and Berglund (1966). Some samples were undersized and therefore diluted. Amount of $\mathrm{CO}_{2}$ from sample is given in Comments below as "\% sample". All samples pretreated with $\mathrm{HCl}$.

\section{Lu-893. Tomtabacken 1,519 to $522 \mathrm{~cm}$

$$
\begin{gathered}
12,610 \pm 190 \\
10,660 \text { BC } \\
\delta^{1 s} C=-21.4 \%
\end{gathered}
$$

Muddy, silty clay. Comment: $0.18 \%$ carbonate content in sediment from 530 to $535 \mathrm{~cm} .47 \%$ sample. (3 1-day counts.)

\section{Lu-894. Tomtabacken 2,517 to $519 \mathrm{~cm}$ \\ $10,500 \mathrm{BC}$ \\ $\delta^{13} C=-22.6 \%$}

Clay gyttja. Sample 1 and 2 should date Betula rise in pollen diagram. Comment: $74 \%$ sample. (3 1-day counts.)

\section{Lu-895. Tomtabacken 3, 509 to $512 \mathrm{~cm}$}

$$
\begin{gathered}
11,480 \pm 115 \\
9530 \mathrm{BC} \\
\delta^{1 s} C=-23.2 \% \text { 。 }
\end{gathered}
$$

Clay gyttja. Upper part of Betula zone. Comment: no detectable carbonate in sample.

\section{Lu-896. Tomtabacken 4, 506 to $509 \mathrm{~cm}$}

Clay gyttja. Lower part of DR 3.

$$
\begin{gathered}
10,440 \pm 110 \\
8490 \mathrm{BC} \\
\delta^{13} C=-22.3 \%
\end{gathered}
$$

Lu-897. Tomtabacken 5,491 to $493 \mathrm{~cm}$

Clay gyttja. Upper part of DR 3. Comment: $85 \%$ sample.

\section{Lu-898. Tomtabacken 6,489 to $491 \mathrm{~cm}$}

Clay gyttja. Lower part of DR 3-PB. Comments: $52 \%$ sample. (3 1-day counts.) (BEB): for some reason this date deviates from the continuous chronologic order.

\section{Lu-899. Tomtabacken 7,486 to $487 \mathrm{~cm}$}

$$
\begin{gathered}
10,150 \pm 115 \\
8200 \text { BC } \\
\delta^{13} C=-23.5 \%
\end{gathered}
$$

Clay gyttja. Uppermost part of DR 3-PB. Comment: $82 \%$ sample. 
Lu-900. Tomtabacken 8,479 to $480 \mathrm{~cm}$

$9860 \pm 85$

7910 BC

$\delta^{13} \mathrm{C}=-27.3 \%$ o counts.)

Clayey gyttja. Middle of PB. Comment: $92 \%$ sample. (3 1-day

\section{Lu-901. Tomtabacken 9, 474 to $475 \mathrm{~cm}$}

$9530 \pm 95$

$7580 \mathrm{BC}$

Clayey gyttja. Uppermost part of PB.

$\delta^{13} C=-27.7 \%$

Lu-902. Tomtabacken 10,468 to $469 \mathrm{~cm}$

Clayey gyttja. Middle of BO 1.

$9120 \pm 95$

$7170 \mathrm{BC}$

$\delta^{1 s} C=-30.6 \%$ o

Lu-903. Tomtabacken 11,462 to $463 \mathrm{~cm}$

$8470 \pm 95$

$6520 \mathrm{BC}$

$\delta^{13} \mathrm{C}=-31.0 \%$ sample.

Fine detritus gyttja. Lowermost part of BO 2. Comment: $93 \%$

Lu-904. Tomtabacken 12,440 to $441 \mathrm{~cm}$

$7640 \pm 80$

$\mathbf{5 6 9 0}$ BC

$\delta^{13} C=-30.3 \%$

Fine detritus gyttja. Lower part of AT 1.

\section{Lake Ämmern series}

Sediment from Lake Ämmern, 600m NE of Tjärstad church, Östergötland $\left(58^{\circ} 07^{\prime} 30^{\prime \prime} \mathrm{N}, 15^{\circ} 43^{\prime} 30^{\prime \prime} \mathrm{E}\right)$. Alt of lake: +86.1m. Coll 1972 and subm by $\mathrm{H}$ Göransson, Dept Quat Geol, Univ Lund. Lu-924 and -925 taken with $30 \mathrm{~mm}$ and the rest with $60 \mathrm{~mm}$ Livingstone core sampler. All samples consist of fine detritus gyttja. Depths are below sedimentwater interface. Water depth at sampling point, $423 \mathrm{~cm}$. Samples represent characteristic levels in pollen diagram. Pollen analyses by submitter. Dating is part of study on vegetational development and human influence in area. See also Lake Striern and Lake Vån series (R, 1970, v 12, p 541-543; 1974, v 16, p 315-316, and below). All samples pretreated with $\mathrm{HCl}$.

Lu-924. Ämmern, 369 to $379 \mathrm{~cm}$

$6140 \pm 70$

$4190 \mathrm{BC}$

$\delta^{13} C=-28.5 \%$

Immediately below Ulmus decline and at Tilia decline; 1st find of Triticum.

Lu-925. Ämmern, 339 to $349 \mathrm{~cm}$

$5870 \pm 70$

3920 BC

Low Ulmus and Tilia values after decline.

$\delta^{1 s} C=-28.5 \%$ 
Lu-926. Ämmern, 314 to $318 \mathrm{~cm}$

$5760 \pm 70$

$\mathbf{3 8 1 0 ~ B C}$

$\delta^{13} C=-27.3 \%$

Ulmus and Tilia increasing; decline of Populus and Pteridium.

Lu-927. Ämmern, 256 to $260 \mathrm{~cm}$

$5230 \pm 70$

3280 вC

Second decline of Ulmus.

$\delta^{13} \mathrm{C}=-27.9 \%$

Lu-928. Ämmern, 210 to $214 \mathrm{~cm}$

$4840 \pm 65$

$2890 \mathrm{BC}$

Further decline of Ulmus; rising Pteridium.

$\delta^{13} \mathrm{C}=-28.2 \%$

Lu-929. Ämmern, 155 to $160 \mathrm{~cm}$

$3980 \pm 60$

2030 BC

$\delta^{13} C=-28.2 \%$

Falling Quercetum Mixtum. Increase of apophytes and anthropochors.

\section{Lu-956. Ämmern, 97.5 to $102.5 \mathrm{~cm}$}

$3140 \pm 55$

Empiric Picea limit. Juniperus strongly rising.

$1190 \mathrm{BC}$

$\delta^{13} C=-27.5 \%$

\section{Lu-957. Ämmern, 85 to $90 \mathrm{~cm}$}

$$
\begin{gathered}
\mathbf{2 7 4 0} \pm \mathbf{5 5} \\
\mathbf{7 9 0} \mathbf{B C} \\
\delta^{13} C=-27.3 \%
\end{gathered}
$$

Picea ca $6 \%$; Juniperus 3 to $4 \%$.

General Comment (HG): in Lake Ämmern, Ulmus declines at same age as in Lake Vån ( $c f \mathrm{R}, 1974, \mathrm{v} 16, \mathrm{p}$ 316-317). $\mathrm{CaCO}_{3}$ content in the till is very low around Lake Vån, but distinctly higher near Lake Ämmern ( $c f$ Gillberg, 1965, p 455). Sedimentation rate is very low in uppermost part of Ämmern profile and there is perhaps some hidden hiatus. Lake Ämmern was lowered ca $3 \mathrm{~m} 100 \mathrm{yr}$ ago.

\section{Lake Striern Series II}

Sediment from Lake Striern, ca $850 \mathrm{~m} \mathrm{E}$ of Hägerstad old church, Östergötland $\left(58^{\circ} 05^{\prime} \mathrm{N}, 15^{\circ} 47^{\prime} \mathrm{E}\right)$. Alt of lake: $+87.3 \mathrm{~m}$. Coll 1972 and subm by $\mathrm{H}$ Göransson. Taken with $60 \mathrm{~mm}$ Livingstone core sampler. All samples consist of fine detritus gyttja. Depths are below sedimentwater interface. Water depth at sampling point, $63 \mathrm{~cm}$. Dated as complement to Lake Striern and Lake Vån series (R, 1970, v 12, p 541-543; 1974, v 16, p 315-316). All samples pretreated with $\mathrm{HCl}$.

Lu-951. Striern II, 430 to $435 \mathrm{~cm}$

$7610 \pm 80$

Empiric Quercus limit.

5660 вC

$\delta^{13} \mathrm{C}=-30.4 \%$ 
Lu-952. Striern II, 420 to $425 \mathrm{~cm}$

Empiric Tilia limit.

Lu-953. Striern II, 415 to $420 \mathrm{~cm}$

Rational Tilia limit.
$7090 \pm 80$

5140 BC

$\delta^{13} \mathrm{C}=-30.2 \%$

$6790 \pm 75$

4840 BC

$\delta^{13} C=-30.1 \%$

$6050 \pm 70$

$4100 \mathrm{BC}$

$\delta^{13} C=-25.2 \%$ o

Optimum of "Older Lime Period" (sensu Iversen, 1973, p 62).

\section{Lu-955. Striern II, 340 to $345 \mathrm{~cm}$}

$5620 \pm 70$

3670 BC

$\delta^{13} C=-24.9 \%$

Immediately below Ulmus decline; immediately above Tilia decline; strong rise of Populus.

\section{Lu-950. Striern II, 320 to $325 \mathrm{~cm}$}

$5250 \pm 65$

3300 BC

$\delta^{13} C=-23.0 \%$

Low values of Ulmus and Tilia after decline; high values of Populus, Pteridium, and Rumex acetocella; continuous curve for Plantago lanceolata (since $325 \mathrm{~cm}$ ); find of Triticum.

General Comment (HG): real radiocarbon age for Ulmus decline in Striern I (R, 1970, v 12, p 542) and Striern II seem exactly the same, considering dated sample in Striern I was from above and in Striern II below decline.

\section{Lu-949. Striern I, 10 to $20 \mathrm{~cm}$}

$$
\begin{array}{r}
\mathbf{5 0 0} \pm \mathbf{8 0} \\
\text { AD } 1450 \\
\delta^{1 s} C=-25.3 \%
\end{array}
$$

Fine detritus gyttja, Sample $102+103$, with high values of Myriophyllum spicatum and $M$ alterniflorum, from Lake Striern, $900 \mathrm{~m}$ NE of Hägerstad new church, Östergötland (58 $\left.05^{\prime} \mathrm{N}, 15^{\circ} 47^{\prime} \mathrm{E}\right)$. Coll 1966 and subm by H Göransson. Complement to Lake Striern series (R, 1970, v 12, p 541-543). Pretreated with HCl. Undersized; diluted; $39 \%$ sample. Comment (HG): because lake was lowered $100 \mathrm{yr}$ ago, ${ }^{14} \mathrm{C}$ ages of uppermost part of Striern I core are wrong. Thus, it is not possible to determine a value for "hard water error" by extending the ${ }^{14} \mathrm{C}$ curve to the sediment surface. Also, ${ }^{14} \mathrm{C}$ values in lowered lakes in Southern Swedish Highlands without $\mathrm{CaCO}_{3}$ in surroundings are too high (see, eg, Lu-862, Hinnasjön series, above).

\section{Lu-945. Bönnarp}

$$
\begin{gathered}
11,490 \pm 105 \\
\mathbf{9 5 4 0} \mathbf{B C} \\
\delta^{13} C=-19.1 \% 0
\end{gathered}
$$

Collagen from metatarsus (Megaceros giganteus) from small ancient 
lake at Bönnarp, SE of Malmö (55 $\left.35^{\prime} \mathrm{N}, 13^{\circ} 07^{\prime} \mathrm{E}\right)$. Coll 1972 by Limhamn Mus; subm by R Liljegren, Dept Quaternary Geol, Univ Luncl. Comments: collagen extracted as described previously (R, 1970, $\mathrm{v}$ 12, p 534). Organic carbon content: $4.2 \%$. (RL): pollen study not possible, but result agrees well with date for antler of Megaceros giganteus from Hindby (Lu-824: 11,330 $\pm 110, \mathrm{R}, 1974, \mathrm{v} 16, \mathrm{p} 317)$.

\section{Bäckebol series, marine shells}

Marine shells from E of pt 82, Bäckebol, Hisingen, SW Sweden $\left(57^{\circ} 46^{\prime} \mathrm{N}, 11^{\circ} 59^{\prime} 08^{\prime \prime} \mathrm{E}\right)$. Coll 1961 and subm by $\AA$ Hillefors, Dept Phys Geog, Univ Lund. Dated as part of study of chronology for terminal moraine lines at Swedish W coast.

\section{$11,000 \mathrm{BC}$ $\delta^{13} \mathrm{C}=-0.8 \%$ o}

Shells (Mytilus edulis) from sandy shell accumulation enclosed in till ( $c f$ Hillefors, 1969, p 154, 156: fig 139a). Comment: inner fraction $(35 \%$ of shells) was used.

\section{Lu-876:1. Bäckebol, Mytilus, outer fraction $10,830 \mathrm{BC}$ \\ $\delta^{13} C=-0.8 \%$}

Outer fraction of shells used for Lu-876:2. Comment: outer fraction was $39 \%$ of shells; outermost $26 \%$ removed by acid leaching.

\section{Lu-877. Bäckebol, Hiatella}

$$
\begin{aligned}
& 12,580 \pm 125 \\
& 10,630 \mathrm{BC} \\
& \delta^{13} C=+1.2 \%
\end{aligned}
$$

Shells (Hiatella [Saxicava] arctica) from wave-washed gravel overlying upper till boundary. Comment: outer $53 \%$ of shells removed by acid leaching.

General Comment: other pertinent dates are Lu-270: 12,880 \pm 125 ; Lu-271: 12,960 \pm 135 ; Lu-281: 12,880 \pm 145; Lu-507: 12,890 \pm 130 (R, 1970, v 12, p 544-545; 1972, v 14, p 386). Corrections for deviations from $\delta^{13} C=-25.0 \%$ in PDB scale are applied also for shell samples. No corrections are made for apparent age of shells of living marine mollusks. For apparent age, see Recent marine shells series below, and R, 1969, v 11, p 441; 1970, v 12, p 543.

\section{Recent marine shells series}

Lu-593. Slussen, Orust, Sample 1 Apparent age: $420 \pm 45$ $\delta^{18} C=-0.4 \%$

Recent shells (Nassa reticulata) from seashore at Slussen, Orust, Bohuslän $\left(58^{\circ} 15^{\prime} 07^{\prime \prime} \mathrm{N}, 11^{\circ} 45^{\prime} 05^{\prime \prime} \mathrm{E}\right)$. Coll 1942 by G Hillefors; subm by $\AA$ Hillefors. 
Lu-594. Slussen, Orust, Sample 2 Apparent age: $380 \pm 48$ $\delta^{13} \mathrm{C}=+0.8 \%$

Recent shells (Cardium edule, Nassa reticulata, Littorina obtusata, and Mytilus edulis) from same collection as Lu-593.

Lu-878. Skagen, Jutland, Sample 1 Apparent age: $375 \pm 44$ $\delta^{13} \mathrm{C}=+0.2 \%$

Recent shells (Mya arenaria) from seashore between Skagen and Grenen, Jutland, N Denmark (57 $\left.47^{\circ} \mathrm{N}, 10^{\circ} 37^{\prime} 40^{\prime \prime} \mathrm{E}\right)$. Coll 1937 by G Hillefors; subm by $\AA$ Hillefors. Comment: outer $25 \%$ removed by acid leaching.

General Comment: corrections are applied for deviations from $\delta^{13} C=$ $-25.0 \%$ in PDB scale and activity measurements are age-corrected between collection date and 1950.

\section{Tertiary shell series}

Tertiary shell fragments from exposure at mouth of Hallbjarnarstadaá, Tjörnes, Iceland $\left(66^{\circ} 11^{\prime} \mathrm{N}, 17^{\circ} 11^{\prime} \mathrm{W}\right)$. Coll 1971 by I U Olsson, Inst Phys, Univ Uppsala, to test whether fossil shells remain uncontaminated by ${ }^{14} \mathrm{C}$ under favorable environmental conditions.

Lu-591. Hallbjarnarstadaá, inner fraction

$\delta^{13} \mathrm{C}=+0.8 \%$

Unid. Tertiary shell fragments. Comment: inner fraction $(42 \%$ of shells) was used. (5 1-day counts.)

\section{Lu-590. Hallbjarnarstadaá, outer fraction}

$$
\begin{array}{r}
>\mathbf{4 3 , 6 0 0} \\
\delta^{13} C=+0.5 \% \text { \% }
\end{array}
$$

Outer fraction of shells used for Lu-591. Comment: outer fraction was $38 \%$ of shells; outermost $20 \%$ removed by acid leaching. (5 1-day counts.)

General Comment: shells had no detectable contamination. Measured activity was almost exactly zero for both fractions. Three $\sigma$ were used for calculation of minimum age.

\section{B. Greenland}

\section{East Greenland series (IV)}

Marine shells from emerged sediments, and terrestrial peat, from different parts of central $\mathrm{E}$ and NE Greenland (mainly from Hudson Land and Hold With Hope). Sample Lu-930 coll 1907 by Danmark Expedition; all others coll 1970 to 1973 by C Hjort, Dept Quaternary Geol, Univ Lund, who subm all samples as part of study of glaciation chronology and shoreline displacement in E Greenland. For other dates from area, see R, 1972, v 14, p 388-390; 1973, v 15, p 504-507; 1974, v 16, p 319-322. For apparent age of recent shells in area, see R, 1973, v 15, p 506-507 and Hjort (1973). 


\section{Lu-866. Forsblads Fjord, Sample 1}

$7140 \pm 75$

5190 BC

$\delta^{13} \mathrm{C}=+0.7 \%$

Shells (Mya truncata, Hiatella arctica) from silty sand at $+21 \mathrm{~m}$, inner Forsblads Fjord $\left(72^{\circ} 24^{\prime} \mathrm{N}, 26^{\circ} 14^{\prime} \mathrm{W}\right)$. Sediment also contained Mytilus edulis (Hjort \& Funder, 1974). Comment: outer $62 \%$ of shells removed by acid leaching.

\section{Lu-867. Loch Fyne, Sample 1}

$6500 \pm 75$

4550 BC

$\delta^{13} \mathrm{C}=+0.1 \%$

Shells (Mytilus edulis) from coastal cliff on $\mathrm{W}$ side of Loch Fyne $\left(73^{\circ} 40^{\prime} \mathrm{N}, 21^{\circ} 50^{\prime} \mathrm{W}\right)$. Antedates shoreline at $+7 \mathrm{~m}$ to $+8 \mathrm{~m}$ (cf Hjort \& Funder, 1974). Comment: outer $50 \%$ of shells removed by acid leaching.

\section{Lu-868. Ankerbjaergelv}

$6460 \pm 70$

$4510 \mathrm{BC}$

Shells (Mya truncata, Macoma calcarea, Clinocardium ciliatum) from fine sand overlain by beach gravel at Ankerbjaergelv delta in Moskusoxefjord $\left(73^{\circ} 37^{\prime} \mathrm{N}, 22^{\circ} 21^{\prime} \mathrm{W}\right)$. Coll at $+2 \mathrm{~m}$ and dates or closely antedates shore level at $+6 \mathrm{~m}$. Also contained fragments of Mytilus edulis (cf Hjort \& Funder, 1974). Comment: outer $44 \%$ of shells removed by acid leaching.

$$
\begin{array}{cc}
42,500 & \\
\text { Lu-869. Knudshoved, Sample } 1 & -2500 \\
40,550 ~ \mathbf{~ B C} \\
\delta^{13} C=+0.5 \%
\end{array}
$$

Shell fragments (Mya truncata, Hiatella arctica) from silt at $+50 \mathrm{~m}$ on basalt hill with glacial striae at Knudshoved, Hold With Hope $\left(73^{\circ}\right.$ $\left.44^{\prime} \mathrm{N}, 20^{\circ} 32^{\prime} \mathrm{W}\right)$. Probably postdates glaciation reaching outer coast and shelf (Kap Mackenzie Stadial; Funder \& Hjort, 1973). Comment: outer $25 \%$ of shells removed by acid leaching. (4 1-day counts.)

\section{Lu-882. Glommen}

$$
\begin{gathered}
10,720 \pm 150 \\
8770 \mathrm{BC} \\
\delta^{13} C=-4.1 \% 0
\end{gathered}
$$

Shells (Hiatella arctica) from sandy silt at $+45 \mathrm{~m}$ along $\mathrm{R}$ Glommen, Hold With Hope $\left(73^{\circ} 33^{\prime} \mathrm{N}, 20^{\circ} 45^{\prime} \mathrm{W}\right)$. Clearly antedates sea level at $+50 \mathrm{~m}$. Same sediment reaches ca $+60 \mathrm{~m}$, with no shells much above sample layer. Comment: outer $21 \%$ of shells removed by acid leaching. Undersized; diluted; $50 \%$ sample. (3 1-day counts.)

\section{Lu-883. Stordalen}

$$
9220 \pm 90
$$
$7270 \mathrm{BC}$ $\delta^{1 s} C=+1.2 \%$

Shells (Mya truncata, Hiatella arctica) from silt at $+35 \mathrm{~m}$, at mouth of Stordalen, Hudson Land $\left(73^{\circ} 40^{\prime} \mathrm{N}, 22^{\circ} 00^{\prime} \mathrm{W}\right)$. Age is minimum for 
moraine system equivalent to shore level at $+70 \mathrm{~m}$. Probably dates icecontact delta rather closely at $+60 \mathrm{~m}$. Comment: outer $16 \%$ of shells removed by acid leaching.

\section{Lu-884. Myggbukta}

Shells (Mya truncata, Tridonta [Astarte] borealis, Nicania [Astarte] montagui) from fine sand at ca $+6 \mathrm{~m}$, overlain by seaweed, organic detritus, and eolian sand at Myggbukta $\left(73^{\circ} 29^{\prime} \mathrm{N}, 21^{\circ} 37^{\prime} \mathrm{W}\right)$. Probably closely dates distinct shore level at $+7 \mathrm{~m}$. Comment: outer $21 \%$ of shells removed by acid leaching.

\section{Lu-885. Tobias Dal}

$9540 \pm 90$

$7590 \mathrm{BC}$

$\delta^{13} C=+0.3 \%$

Shells (Mya truncata, Hiatella arctica) from silty fine sand at $+20 \mathrm{~m}$ in Tobias Dal, Hold With Hope $\left(73^{\circ} 44^{\prime} \mathrm{N}, 20^{\circ} 45^{\prime} \mathrm{W}\right)$. Sediment reaches $+30 \mathrm{~m}$, the highest for shell-bearing known in this valley. Comment: outer $62 \%$ of shells removed by acid leaching.

\section{Lu-886. Loch Fyne, Sample 2}

$9290 \pm 90$

7340 вC

$\delta^{13} \mathrm{C}=+0.8 \%$ o

Shells (Mya truncata) from fine sand at +35 to $40 \mathrm{~m}$ on W side of Loch Fyne $\left(73^{\circ} 41^{\prime} \mathrm{N}, 21^{\circ} 50^{\prime} \mathrm{W}\right)$. Equivalent to shore level at or above $+52 \mathrm{~m}$. Comment: outer $63 \%$ of shells removed by acid leaching.

\section{Lu-930. Store Koldewey}

$>40,400$

$$
\delta^{13} \mathrm{C}=-0.7 \%
$$

Shells (Mya truncata, Hiatella arctica, Macoma calcarea, Clinocardium ciliatum, Serripes groenlandica, Tridonta borealis, Natica sp, Nucula $\mathrm{sp}$, Portlandia arctica) from clay on bedrock at $+120 \mathrm{~m}$ on $\mathrm{S}$ part of Store Koldewey Ö $\left(76^{\circ} 10^{\prime} \mathrm{N}, 18^{\circ} 35^{\prime} \mathrm{W}\right)$. Coll during Danmark Expedition, 1907; described by Jensen (1917). Date is linked with age of glaciation reaching outer coast and shelf ( $c f$ Kap Mackenzie Stadial; Funder \& Hjort, 1973). Alt compares with that of Lu-532 (R, 1973, v 15, p 504). Sample also contained Cyrtodaria kurriana (cf Símonarson, 1974, p 68). Comment: outer $10 \%$ of shells removed by acid leaching. Sample undersized; diluted; $78 \%$ sample. (3 1-day counts.)

\section{Lu-972. Knudshoved, Sample 2}

$$
\begin{gathered}
2090 \pm 60 \\
140 \text { BC } \\
\delta^{13} C=-26.5 \% 0
\end{gathered}
$$

Terrestrial sandy peat from river cutting at $+35 \mathrm{~m}$, Knudshoved, Hold With Hope $\left(73^{\circ} 43^{\prime} \mathrm{N}, 20^{\circ} 34^{\prime} \mathrm{W}\right)$. Cioll at top of permafrost, into which these sediments continue; overlain by $2 \mathrm{~m}$ alternating layers of same kind of peat and eolian sand. Comment: pretreated with HCl and $\mathrm{NaOH}$. Diluted; $81 \%$ sample.

General Comment: corrections for deviations from $\delta^{13} C=-25.0 \%$ in 
PDB scale are applied also for shell samples. No corrections are made for apparent age of shells of living marine mollusks.

\section{Nottinghambukta series}

$$
\text { C. Spitsbergen }
$$

Marine shells and plant remains from cliff shore of Kvartsittsletta in Nottinghambukta near Werenskiold Glacier, $\mathrm{N}$ of Hornsund, S part of Vest-Spitsbergen $\left(77^{\circ} 04^{\prime} 20^{\prime \prime} \mathrm{N}, 15^{\circ} 10^{\prime} \mathrm{E}\right)$. Coll 1972 by J Szupryczyński and A Olszewski; subm by J Szupryczyński, Inst Geog, Polish Acad Sci, Toruń, Poland. Mollusks id by I Dmoch, N Copernicus Univ, Torun. Depths refer to surface of " 5 to $4 \mathrm{~m}$ marine terrace". Results of studies from Hornsund area pub by Birkenmajer and Olsson (1971).

\section{Lu-847. Nottinghambukta N-1, 0.5 to $1.2 \mathrm{~m}$ $\mathbf{5 3 4 0 ~ B C}$ \\ $\delta^{13} \mathrm{C}=+1.3 \% \mathrm{c}$}

Shells (Tridonta [Astarte] borealis) from gray and brown marine gravel and sand. Fauna in interval 0.5 to $1.2 \mathrm{~m}$ also contained Mytilus edulis. Comment: outer $70 \%$ of shells removed by acid leaching.

\section{Lu-848. Nottinghambukta $\mathbf{N}-2,1.2$ to $1.8 \mathrm{~m}$}

$7310 \pm 75$

5360 вС

$\delta^{13} C=-0.1 \%$ 。

Shells (Mytilus edulis) from gray marine sand and gravel. Fauna in this interval also contained Tridonta (Astarte) borealis. Comment: outer $63 \%$ of shells removed by acid leaching.

\section{Lu-849. Nottinghambukta $\mathrm{N} \cdot 3: 1,1.7$ to 5350 BC \\ $\delta^{13} C=+0.4 \%$}

Shells (Mytilus edulis) from gray marine sand. Comment: outer $65 \%$ of shells removed by acid leaching.

\section{Lu-850. Nottinghambukta $\mathrm{N}-3: 2,1.7$ to $2.2 \mathrm{~m}$ \\ $7490 \pm 75$ \\ $\mathbf{5 5 4 0}$ BC$$
\delta^{13} \mathrm{C}=+1.6 \%
$$

Shells (Tridonta [Astarte] borealis) from same deposits as Lu- 849 . Comment: outer $65 \%$ of shells removed by acid leaching.

\section{Lu-812. Nottinghambukta N-4:1, 2.2 to $3.5 \mathrm{~m}$}

$$
\begin{gathered}
\mathbf{7 5 8 0} \pm 75 \\
\mathbf{5 6 3 0} \mathbf{B C} \\
\delta^{13} C=-1.1 \% \circ
\end{gathered}
$$

Shells (Mytilus edulis) from gray marine very fine sand. Fauna in this interval also included Hiatella (Saxicava) arctica, Tridonta (Astarte) borealis, Mya truncata, Littorina littorea, and unid. barnacles. Comment: outer $67 \%$ of shells removed by acid leaching.

\section{BC \\ $\delta^{13} \mathrm{C}=+0.1 \%$}

Barnacle shells from same deposits as Lu-812. Comment: outer $60 \%$ of shells removed by acid leaching. 
Lu-851. Nottinghambukta N-4:3, 2.3 to $2.4 \mathrm{~m} \quad \begin{array}{r}\mathbf{7 4 0 0} \pm \mathbf{5 0} \\ \mathbf{5 4 5 0} \mathrm{BC} \\ \delta^{13} C=-20.0 \%\end{array}$

Remains of unid. littoral plants from top part of interval N-4. Comment: pretreated with $\mathrm{HCl}$ and $\mathrm{NaOH}$.

General Comment: corrections for deviations from $\delta^{13} \mathrm{C}=-25.0 \%$ in PDB scale are applied also for shell samples. No corrections are made for apparent age of shells of living marine mollusks.

\section{Poland}

Lu-852. Grudziadz-Mniszek

$\begin{aligned} & >\mathbf{4 0 , 2 0 0} \\ \delta^{13} C & =-27.2 \% 0\end{aligned}$

Highly humified organic matter from boring at Grudziądz-Mniszek, lower Vistula valley, N Poland $\left(53^{\circ} 26^{\prime} \mathrm{N}, 18^{\circ} 44^{\prime} \mathrm{E}\right)$. Sample from middle part of upper organic layer, ca 10 to $12 \mathrm{~m}$ below surface of Vistula Terrace II, overlain by sand and alluvium (Drozdowski and Tobolski, 1972, p 77; p 88, fig 3). Coll 1969 and subm by E Drozdowski, Inst Geog, Polish Acad Sci, Toruń, Poland. Comment: normal pretreatment with $\mathrm{HCl}$ but only short treatment with $\mathrm{NaOH}$ at room temperature due to high humification.

Lu-852A. Grudziadz-Mniszek, humic acid

$$
\begin{array}{r}
>\mathbf{3 9 , 6 0 0} \\
\delta^{13} \mathrm{C}=-25.7 \%
\end{array}
$$

Acid-precipitated part of $\mathrm{NaOH}$-soluble fraction from $\mathrm{Lu}-852$.

\section{E. Scotland}

\section{Lu-916. Rannoch Moor}

$5850 \pm 70$ 3900 BC

$\delta^{18} \mathrm{C}=-24.9 \%$

Wood from pine stump $30 \mathrm{~cm}$ over base of rather humified peat layer $(110 \mathrm{~cm}$ deep) of gently sloping valley bog in W part of Rannoch Moor, $10 \mathrm{~km} \mathrm{~N}$ of Loch Tulla, Argyll, Scotland (56 $\left.36^{\circ} \mathrm{N}, 4^{\circ} 48^{\prime} \mathrm{W}\right)$. Coll 1973 and subm by N Malmer, Dept Plant Ecol, Univ Lund. Sample was part of distinct stump horizon without contact with underlying mineral substratum of gravel. Comment (NM): stump horizon dates last time for formation of peat in this area. $C f$ previous dates for similar samples from Ireland ( R, 1974, v 16, p 322-323). Pretreated with HCl and $\mathrm{NaOH}$.

\section{ARCHAEOLOGIC SAMPLES} Sweden

\section{Dalkarlstorp series}

Charcoal and soot from Stone age settlement at Dalkarlstorp, Kila parish, Västmanland (59 $\left.59^{\circ} \mathrm{N}, 16^{\circ} 30^{\prime} 30^{\prime \prime} \mathrm{E}\right)$. Coll 1972 and 1973 and subm by $S$ Welinder, Hist Mus, Univ Lund. Preliminary report pub by submitter (Welinder, 1973). All samples pretreated with $\mathrm{HCl}$ or $\mathrm{H}_{2} \mathrm{SO}_{4}(\mathrm{Lu}-776,-776: \mathrm{S} 2)$ and $\mathrm{NaOH}$. 


\section{Lu-748. Dalkarlstorp 1}

Charcoal from Hearth-pit 492/9.

\section{Lu-749. Dalkarlstorp 2}

Charcoal from Pit 580/40.

\section{Lu-750. Dalkarlstorp 3}

Charcoal from Hearth-pit 496/18.

\section{Lu-776. Dalkarlstorp 4}

$$
\begin{gathered}
4080 \pm 60 \\
2130 \text { BC } \\
\delta^{13} C=-24.8 \% \text { \% }
\end{gathered}
$$

$$
\begin{gathered}
1670 \pm 50 \\
\text { AD 280 } \\
\delta^{13} C=-24.8 \%
\end{gathered}
$$

$$
\begin{gathered}
\mathbf{5 5 2 0} \pm \mathbf{6 5} \\
\mathbf{3 5 7 0} \mathbf{\text { BC }} \\
\delta^{13} C=-23.5 \% \text {. }
\end{gathered}
$$

$$
\begin{gathered}
\mathbf{5 8 7 0} \pm \mathbf{7 5} \\
\mathbf{3 9 2 0} \mathbf{B C} \\
\delta^{13} C=-24.5 \%
\end{gathered}
$$

Charcoal $>1 \mathrm{~mm}$ from sooty sand from Hearth-pit 275/24. Comment: sample undersized; diluted; $88 \%$ sample. Charcoal separated from ca $4.5 \mathrm{~kg}$ sand by screening and subsequent immersion in ca $40 \% \mathrm{H}_{2} \mathrm{SO}_{4}$ (heavy liquid separation).

\section{Lu-776:S1. Dalkarlstorp 4, soot, Sample 1

$$
\begin{aligned}
& 4150 \pm 60 \\
& 2200 \mathrm{BC}
\end{aligned}
$$$$
\delta^{18} C=-24.4 \%
$$

Soot and other organic material $<1 \mathrm{~mm}$, from another $1 \mathrm{~kg}$ portion Lu-776. Comment: organic content enriched to ca $10 \%$ by rotation of suitable portions of sooty sand in distilled water, followed by decantation. Normal $\mathrm{HCl}$ pretreatment but only very short treatment with $\mathrm{NaOH}$.

\section{Lu-776:S2. Dalkarlstorp 4, soot, Sample 2}

$$
\begin{gathered}
4300 \text { ㄴ } 105 \\
\mathbf{2 3 5 0} \text { BC } \\
\delta^{13} C=-23.8 \% \text {. }
\end{gathered}
$$

Soot and other organic material $<1 \mathrm{~mm}$, from another $1 \mathrm{~kg}$ portion of same sand as Lu-776. Comment: organic content enriched to ca $10 \%$ by immersion of suitable portions of sooty sand in ca $60 \% \mathrm{H}_{2} \mathrm{SO}_{4}$. Short treatment with $\mathrm{NaOH}$ dissolved ca $65 \%$ of obtained organic matter. Sample therefore undersized; diluted; $45 \%$ sample.

$$
\text { Lu-776:S2A. Dalkarlstorp 4, soot, Sample 2A } \begin{array}{r}
\mathbf{4 7 3 0} \pm \mathbf{2 7 0} \\
\mathbf{2 7 8 0} \mathbf{B C}
\end{array}
$$

Acid-precipitated part of NaOH-soluble fraction from Lu-776:S2. Comment: undersized; diluted; $85 \%$ sample.

\section{Lu-777. Dalkarlstorp 5}

$$
\begin{gathered}
\mathbf{1 5 5 0} \pm \mathbf{5 0} \\
\mathbf{A D} \mathbf{4 0 0} \\
\delta^{13} C=-24.2 \%
\end{gathered}
$$

Charcoal from Hearth-pit 275/29. 


\section{Lu-778. Dalkarlstorp 6}

Charcoal from Hearth-pit 321/20.

\section{Lu-907. Dalkarlstorp 7}

Charcoal from Hearth-pit 494/7.

\author{
$5540 \pm 65$ \\ $3590 \mathrm{BC}$ \\ $\delta^{13} C=-23.3 \% c$
}

$$
\begin{gathered}
4010 \pm 60 \\
\mathbf{2 0 6 0} \mathbf{B C} \\
\delta^{13} C=-25.0 \%
\end{gathered}
$$

\section{Gårdlösa series}

Charcoal and bone from Gårdlösa, Smedstorp parish, SE Scania $\left(55^{\circ} 34^{\prime} \mathrm{N}, 14^{\circ} 08^{\prime} \mathrm{E}\right)$. Coll 1973 and subm by B Stjernquist, Hist Mus, Univ Lund. Dated for study of continuity of settlement in Gårdlösa area. For other dates from area and references, see R, 1972, v 14, p 264-266, $392-393 ; 1973$, v 15, p 510-511; 1974, v 16, p 326. Charcoal samples pretreated with $\mathrm{HCl}$ and $\mathrm{NaOH}$. Bone collagen extracted by use of modified Longin method (1971) based on the solubility of collagen in slightly acidic hot water.

\section{Lu-835. Gårdlösa 11, Grave 105}

$$
\begin{gathered}
\mathbf{1 2 7 0} \pm \mathbf{5 5} \\
\mathrm{AD} 680 \\
\delta^{13} \mathrm{C}=-25.1 \%
\end{gathered}
$$

Charcoal from hearth near Grave 105. Depth ca $20 \mathrm{~cm}$. Comment: sample undersized; diluted; $80 \%$ sample. (BS): date shows that hearth and grave are of same age.

\section{Lu-834. Gårdlösa 11, Grave 110}

$$
\begin{array}{r}
\mathbf{3 4 0} \pm \mathbf{5 0} \\
\mathbf{A D} \mathbf{1 6 1 0} \\
\delta^{13} C=-23.9 \%
\end{array}
$$

Charcoal from pit in Grave 110 . Depth ca $30 \mathrm{~cm}$. Comment (BS): unexpected young date; charcoal apparently not contemporaneous with grave.

\section{Lu-853. Gårdlösa 11, Grave 111, Sample 1}

$$
\begin{array}{r}
\mathbf{1 3 2 0} \pm \mathbf{5 0} \\
\mathbf{A D} 630 \\
\delta^{13} C=-25.4 \% 0
\end{array}
$$

Charcoal from pit at N side of Grave 111 . Depth 15 to $30 \mathrm{~cm}$. Comment (BS): date shows that pit is younger than grave (see Lu-908 below) and probably connected to adjacent Migration-period features.

$$
\text { Lu-908. Gårdlösa 11, Grave 111, Sample } 2 \quad \begin{gathered}
1930 \pm 50 \\
\text { AD } 20 \\
\delta^{13} C=-20.3 \%
\end{gathered}
$$

Collagen from human femur from Grave 111. Depth 40 to $45 \mathrm{~cm}$ below top layer of grave. Assoc with pottery and iron awl. Comment: organic carbon content: $2.4 \%$. (BS): date agrees well with time estimate based on assoc archaeol finds. 


\section{Lu-978. N Kverrestad $5^{50}$, House 1}

$1420 \pm 50$

AD 530

$\delta^{13} C=-24.2 \%$

Charcoal from hearth in pit-house at $\mathrm{N}$ Kverrestad $5^{50}$, SE Scania $\left(55^{\circ} 32^{\prime} \mathrm{N}, 14^{\circ} 03^{\prime} 30^{\prime \prime} \mathrm{E}\right)$. Coll 1973 and subm by B Stjernquist. Assoc with stamp ornamented pottery. Pretreated with $\mathrm{HCl}$ and $\mathrm{NaOH}$. Comment (BS): date of importance for dating of: 1) this type of settlement with pit-houses; 2) a special kind of stamp ornamented pottery.

\section{Hindby Mosse series}

Poorly preserved bone fragments of cloven-hoofed animals from Middle Neolithic occupation layer at Hindby Mosse, Fosie, Malmö ( $55^{\circ}$ $34^{\prime} \mathrm{N}, 13^{\circ} 03^{\prime} \mathrm{E}$ ). Coll 1973 and subm by $\mathrm{G}$ Burenhult, Hist Mus, Univ Lund. Bone assoc with flint artifacts and pottery. Depth ca $50 \mathrm{~cm}$. Collagen extracted as described previously (R, 1970, v 12, p 534).

\section{Lu-844. Hindby Mosse, Sample 1}

Collagen from bone fragments from $\mathrm{Sq}$ 14/87. Comment: organic carbon content: $1.2 \%$. Sample undersized; diluted; $70 \%$ sample. (3 I-day counts.)

\section{Lu-845. Hindby Mosse, Sample 2}

$3540 \pm 60$

1590 BC

$\delta^{13} \mathrm{C}=-22.7 \%$

Collagen from rib fragments from $\mathrm{Sq} 13 / 87$. Comment: organic carbon content: $1.7 \%$.

General Comment (GB): date younger than expected since main part of finds from settlement area are Middle Neolithic. There were, however, also some Late Neolithic finds, which may explain the young date.

\section{Lu-971. Tofta Högar}

$$
\begin{gathered}
\mathbf{1 1 8 0} \pm \mathbf{5 0} \\
\mathbf{A D} \mathbf{7 7 0} \\
\delta^{13} C=-25.3 \%
\end{gathered}
$$

Charcoal from fire-layer beneath cairn at Tofta Högar, Hovs parish, Bjäre Peninsula, NW Scania $\left(56^{\circ} 28^{\prime} \mathrm{N}, 12^{\circ} 43^{\prime} \mathrm{E}\right)$. Coll 1974 and subm by $\mathrm{G}$ Burenhult. Pretreated with $\mathrm{HCl}$ and $\mathrm{NaOH}$. Comment (GB): Tofta Högar is primarily a Bronze age cult-place and burial ground. Date indicates secondary use in late Vendel time.

\section{Hagestad series}

Charcoal and bone from Hagestad $6^{2}$ A, Löderup parish, Scania $\left(55^{\circ} 23^{\prime} \mathrm{N}, 14^{\circ} 09^{\prime} \mathrm{E}\right)$. Coll 1973 and subm by M Strömberg, Hist Mus, Univ Lund. For other dates from Hagestad, see R, 1972, v 14, p 394-395; 1973, v 15, p 509; 1974, v 16, p 324. Charcoal samples pretreated with $\mathrm{HCl}$ and $\mathrm{NaOH}$. Bone collagen extracted using the Longin method (1971) based on solubility of collagen in slightly acidic hot water. 
Lu-909. Hagestad $6^{2}$ A, Sample 1:HT73

$$
\begin{gathered}
2080 \pm 50 \\
130 \text { BC } \\
\delta^{13} C=-24.4 \% 0
\end{gathered}
$$

Charcoal from House 1 on field at coast rd S of Rödkillebäcken.

\section{Lu-917. Hagestad 6² A, Sample 3:HT73}

$$
\begin{gathered}
\mathbf{1 2 3 0} \pm \mathbf{5 0} \\
\mathbf{A D} \mathbf{7 2 0} \\
\delta^{13} \mathrm{C}=-22.0 \%
\end{gathered}
$$

Collagen from horse tibia over stone pavement in bog soil near Hagestad Bog; $\mathrm{x}=+5, \mathrm{y}=+0$. Assoc with pottery. Comment: organic carbon content: $5.0 \%$.

\section{Lu-918. Hagestad $6^{2}$ A, Sample 4:HT73}

$$
\begin{gathered}
2160 \pm 50 \\
\mathbf{2 1 0} \text { BC } \\
\delta^{13} C=-21.9 \%
\end{gathered}
$$

Collagen from tibia of cattle from pit below stone pavement at same site as Lu-917; $\mathrm{x}=+7, \mathrm{y}=+1$. Assoc with pottery. Comment: organic carbon content: $4.7 \%$.

Lu-919. Hagestad $6^{2}$ A, Sample 5:HT73

$$
\begin{gathered}
2090 \pm 55 \\
140 \text { BC } \\
\delta^{13} C=-22.9 \% 0
\end{gathered}
$$

Charcoal from hearth at Oven 3 in house foundation. Assoc with bone, pottery, and daub.

Lu-948. Hagestad $6^{2}$ A, Sample 8:73-74

$2140 \pm 55$

Collagen from tibia of cattle from lower peat layer in Trench A: Nov 73. Assoc with pottery. Comment: organic carbon content: $3.8 \%$. General Comment (MS): all dates agree well with results based on archaeol investigation.

\section{Valleberga series}

Charcoal from settlement area with grave field at Valleberga, Scania $\left(55^{\circ} 24^{\prime} \mathrm{N}, 14^{\circ} 04^{\prime} \mathrm{E}\right)$. Coll Oct 1973 to May 1974 and subm by $\mathrm{M}$ Strömberg. For other dates from Valleberga, see R, 1974, v 16, p 324-325. All samples pretreated with $\mathrm{HCl}$ and $\mathrm{NaOH}$.

\section{Lu-910. Valleberga 28, Sample 2:HT73}

$$
\begin{gathered}
2660 \pm 55 \\
710 \text { BC } \\
\delta^{13} C=-25.0 \%
\end{gathered}
$$

Charcoal from hearth connected with poorly developed occupation layer; Trench 2:Oct 1973. Assoc with pottery and flint objects from transition Middle Neolithic-Late Neolithic and overlain by layer with Bronze age artifacts.

Lu-947. Valleberga $5^{2}$, Sample 6:73-74

$$
\begin{gathered}
2330 \pm 55 \\
\mathbf{3 8 0} \mathbf{B C} \\
\delta^{13} \mathrm{C}=-23.1 \%
\end{gathered}
$$

Charcoal from hearth connected with occupation layer. Assoc with 
flint objects and pottery from early Middle-Neolithic Funnel-Beaker culture. Hearth probably connected with Early Iron age burials on same field.

Lu-965. Valleberga $5^{6}$, Sample $9 \mathrm{~b}: 73-74$

$$
\begin{gathered}
3090 \pm 55 \\
1140 \text { BC } \\
\delta^{13} C=-26.5 \% 0
\end{gathered}
$$

Charcoal from oak trunk coffin (Grave I) in burial mound. Assoc with bronze objects from Period III.

Lu-966. Valleberga $5^{6}$, Sample 10:73-74

$$
\begin{gathered}
3140 \pm 55 \\
1190 \mathrm{BC} \\
\delta^{13} C=-25.9 \%
\end{gathered}
$$

Charcoal from oak trunk coffin (Grave II) in burial mound. Assoc with bronze fibula from Period III.

General Comment (MS): dates agree well with archaeol results based on artifact assemblage.

\section{Lu-964. Ingelstorp 19, Sample $7: 73-74$}

$$
\begin{gathered}
\mathbf{1 2 6 0} \pm \mathbf{5 0} \\
\operatorname{AD} 690 \\
\delta^{1 s} \mathrm{C}=-25.7 \% \text { o }
\end{gathered}
$$

Charcoal from hearth on grave field at Ingelstorp 19, Ingelstorp parish, Scania $\left(55^{\circ} 25^{\prime} \mathrm{N}, 14^{\circ} 03^{\prime} \mathrm{E}\right)$. Coll 1974 and subm by M Strömberg. Assoc with millstone. Comment (MS): date confirms estimate based on type of millstone.

\section{Stora Råby series}

Charcoal from Settlement 2 at Stora Råby, Lund, Scania $\left(55^{\circ} 42^{\prime}, \mathrm{N}\right.$, $\left.13^{\circ} 14^{\prime} \mathrm{E}\right)$. Coll 1973 and subm by M Wyszomirski, Hist Mus, Univ Lund. Pretreatment with $\mathrm{HCl}$ and $\mathrm{NaOH}$.

\section{Lu-911. Stora Råby, Pit 1}

$$
\begin{array}{r}
2020 \pm 50 \\
70 \text { BC } \\
\delta^{13} C=-24.7 \% \text { o }
\end{array}
$$

Charcoal from big oval pit with Funnel-Beaker culture artifacts. Roman Iron age artifacts were found near pit.

\section{Lu-912. Stora Råby, Pit 11}

$$
\begin{gathered}
\mathbf{1 2 2 0} \pm \mathbf{5 0} \\
\mathbf{A D} 730 \\
\delta^{13} C=-24.1 \%
\end{gathered}
$$

Charcoal from ca $30 \mathrm{~cm}$ deep post-hole; probably from part of house construction.

\section{Lu-913. Stora Råby, Object 12}

$$
\begin{gathered}
\mathbf{1 3 2 0} \pm \mathbf{5 0} \\
\mathbf{A D 6 3 0} \\
\delta^{13} C=-23.8 \%
\end{gathered}
$$

Charcoal from base of hearth with brittle-burnt stones. Assoc with flint objects and potsherds. 


\section{Lu-914. Stora Råby, Object 21}

Charcoal from walls and bottom of ca $50 \mathrm{~cm}$ deep stone-filled cylindrical pit.

General Comment (MW): dates younger than expected since settlement occupation layer contained much Early Funnel-Beaker culture material (Period A/B). In part of site, features from Migration period (Vendel time) were dug into this occupation layer. Disturbance caused by burrowing animals was noticed and may account for some mixing of material from different periods.

\section{Lu-970. Fårabacken, Löddesborg}

$$
\begin{gathered}
2820 \pm 55 \\
\mathbf{8 7 0} \text { BC } \\
\delta^{13} C=-24.3 \%
\end{gathered}
$$

Charcoal from hearth in Construction 1974:I at Late Neolithic to Early Bronze age site Fårabacken, Löddesborg, Löddeköpinge parish, Scania $\left(55^{\circ} 45^{\prime} \mathrm{N}, 12^{\circ} 59^{\prime} \mathrm{E}\right)$. For other dates from Löddesborg, see R, 1973, v 15, p 508; 1974, v 16, p 328. Coll 1974 and subm by J Callmer, Hist Mus, Univ Lund. Assoc with pottery, burnt bones, flint implements, and flint waste. Pretreated with $\mathrm{HCl}$ and $\mathrm{NaOH}$. Comment (JC): from viewpoint of orthodox chronology, date may seem too late. $C f$, however, Lu-837 from Norrvidinge, $2960 \pm 55$ ( R, 1974, v 16, p 328) and dates from Layer I at Slettab $\phi$ site, Ogna parish, Rogaland, Norway, $2900 \pm$ 100 to $2840 \pm 130$ вP (Skjølsvold, 1972, p 68).

\section{REFERENCES}

Berglund, B E, 1966, Late-Quaternary vegetation in eastern Blekinge, southeastern Sweden. I. Late-Glacial time: Opera Bot A Soc Bot Lundensi, v 12, no. 1, 180 p. Birkenmajer, Krzysztof and Olsson, I U, 1971, Radiocarbon dating of raised marine terraces at Hornsund, Spitsbergen, and the problem of land uplift: Norsk Polarinst Årb 1969, p 17-43.

Digerfeldt, Gunnar, 1972, The Post-Glacial development of Lake Trummen. Regional vegetation history, water level changes and palaeolimnology: Folia Limnol Scandinavica (Lund), no. 16, $104 \mathrm{p}$.

Drozdowski, E and Tobolski, K, 1972, Sites of Eem interglacial in Grudziadz basin; Preliminary information (in Polish with English summary): Badania Fizjograf Nad Polska Zachodnia, v 25, ser A, p 75-91.

Funder, S and Hjort, C, 1973, Aspects of the Weichselian chronology in central East Greenland: Boreas (Oslo), v 2, p 69-84

Gillberg, Gunnar, 1965, Till distribution and ice movements on the northern slopes of the South Swedish Highlands: Geol Fören Stockholm Förh, v 86, p 433-484.

Håkansson, Sören, 1968, University of Lund radiocarbon dates I: Radiocarbon, v 10, p $36-54$.

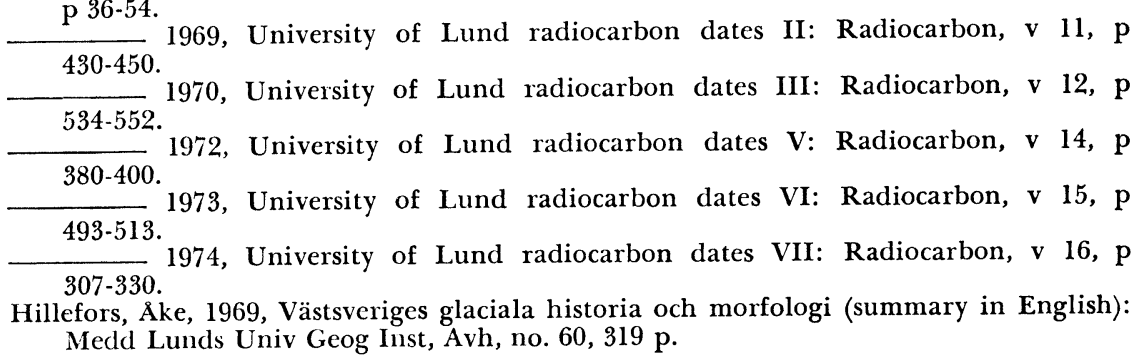


Hjort, Christian, 1973, A sea correction for East Greenland: Geol Fören Stockholm Förh, v 95, p 132-134.

Hjort, C and Funder, S, 1974, The subfossil occurrence of Mytilus edulis L in central East Greenland: Boreas (Oslo), v 3, p 23-33.

Iversen, Johs, 1973, The development of Denmark's nature since the last glacial: Geol Survey Denmark, ser V, no. 7-C, 126 p.

Jensen, Ad S, 1917, Quaternary fossils collected by the Danmark Expedition: Grönland Medd, v 43, no. 21, 11 p.

Longin, Robert, 1971, New method of collagen extraction for radiocarbon dating: Nature, v 230, p 241-242.

Nilsson, Tage, 1961, Ein neues Standardpollendiagramm aus Bjärsjöholmssjön in Schonen: Lunds Univ Årssk, NF avd 2, v 56, no. 18, p 1-34.

Simonarson, L A, 1974, Recent Cyrtodaria and its fossil occurrence in Greenland: Geol Soc Denmark Bull, v 23, p 65-75.

Skjølsvold, A, 1972, Slettabø i Ogna: Viking (Oslo), v 36, p 5-82.

Sonesson, Mats, 1968, Pollen zones at Abisko, Torne Lappmark, Sweden: Bot Notise (Lund), v 121, p 491-500.

Sweden 1974, Late Quaternary forest development of the Torneträsk area, North

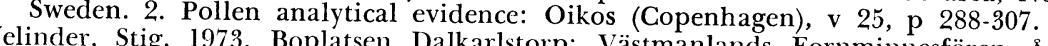

Welinder, Stig, 1973, Boplatsen Dalkarlstorp: Västmanlands Fornminnesfören Årssk (Västerås), v LI, p 5-21. 